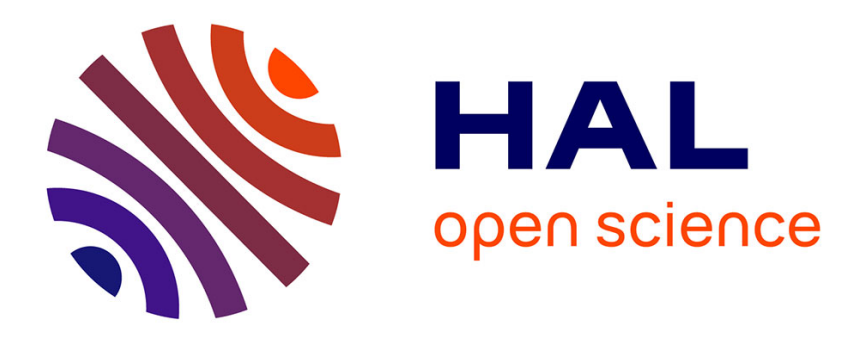

\title{
Plasma prolactin levels during smolting in Atlantic salmon, Salmo salar
}

Patrick Prunet, Gilles Boeuf

\section{To cite this version:}

Patrick Prunet, Gilles Boeuf. Plasma prolactin levels during smolting in Atlantic salmon, Salmo salar. Aquaculture, 1989, 82 (1-4), pp.297-305. 10.1016/0044-8486(89)90416-X . hal-02727995

\section{HAL Id: hal-02727995 \\ https://hal.inrae.fr/hal-02727995}

Submitted on 2 Jun 2020

HAL is a multi-disciplinary open access archive for the deposit and dissemination of scientific research documents, whether they are published or not. The documents may come from teaching and research institutions in France or abroad, or from public or private research centers.
L'archive ouverte pluridisciplinaire HAL, est destinée au dépôt et à la diffusion de documents scientifiques de niveau recherche, publiés ou non, émanant des établissements d'enseignement et de recherche français ou étrangers, des laboratoires publics ou privés. 


\title{
Plasma Prolactin Levels During Smolting in Atlantic Salmon, Salmo salar
}

\author{
PATRICK PRUNET ${ }^{1}$ and GILLES BOEUF ${ }^{2}$ \\ ${ }^{1}$ INRA, Laboratoire de Physiologie des Poissons, Campus de Beaulieu, 35042 Rennes Cedex \\ (France) \\ ${ }^{2}$ IFREMER, Centre de Brest, B.P. 70, 29263 Plouzané (France)
}

\begin{abstract}
Prunet, P. and Boeuf, G., 1989. Plasma prolactin levels during smolting in Atlantic salmon, Salmo salar. Aquaculture, 82: 297-305.

To obtain more information on a possible involvement of prolactin during parr-smolt transformation of Atlantic salmon, Salmo salar, parr and smolt populations of the same age were sampled from February to June. A clear separation of the two populations was observed according to their size and gill $\left(\mathrm{Na}^{+}-\mathrm{K}^{+}\right)$-ATPase activity. Comparison of plasma prolactin (PRL) levels between these two populations indicated a significant decrease from May to early July in smolts whereas, in parr, a steady increase was observed. Diel variations in plasma PRL levels at three different dates were also studied in fish undergoing smolting. Sampling fish over a 24 -h period on 11 March, 5 May and 15 July did not indicate the presence of a diel rhythm in PRL release. These data support the hypothesis that the PRL decrease is associated with smolting in Atlantic salmon and that such a decrease cannot be explained by a change in diel rhythm of plasma PRL levels.
\end{abstract}

\section{INTRODUCTION}

Endocrine control of smoltification involves complex relationships between different hormones bringing about physiological changes that are preparatory for seawater entry. Among different factors, the most clearly defined hormones involved in such control are thyroid hormones and cortisol (Folmar and Dickhoff, 1981; Barton et al., 1985; Grau et al., 1985; Barron, 1986; Langhorne and Simpson, 1986; Boeuf et al., 1989; Young et al., 1989).

The recent development of radioimmunoassays for prolactin (PRL) and growth hormone (GH) in salmonids (Hirano et al., 1985; Prunet et al., 1985; Bolton et al., 1986) has led to a new interest in these pituitary hormones. Developmental studies evaluating plasma GH levels during coho, Oncorhynchus kisutch, and Atlantic salmon smolting indicated a rise of this parameter coinciding with an increase of triiodothyronine, cortisol and gill $\left(\mathrm{Na}^{+}-\mathrm{K}^{+}\right)$ATPase (Prunet et al., 1989; Young et al., 1989). This is in agreement with 
growing evidence of $\mathrm{GH}$ being a seawater adaptive hormone in salmonids (Bolton et al., 1987). Measurement of plasma PRL levels in the same developmental studies indicated a decrease during the period of enhanced adaptability although different patterns where observed in coho and Atlantic salmon (Prunet et al., 1989; Young et al., 1989).

These developmental studies were carried out under natural temperature and photoperiod over a period of several months: PRL changes may be associated with seasonal modifications of these external factors and not with parrsmolt transformation. Moreover, sampling was always at the same time of the day, which does not allow any conclusion on possible changes in daily rhythms of PRL release. In order to investigate these problems, two series of experiments were performed in Atlantic salmon. Diel rhythms in plasma PRL levels were studied over a period of $24 \mathrm{~h}$ at three different dates during smolting. Moreover, plasma PRL levels were followed from February to June in salmon undergoing smolting and compared to levels measured in fish from the same population which remained at the parr stage (lower modal group of the population).

\section{MATERIAL AND METHODS}

\section{Diel rhythm studies (1986)}

Atlantic salmon eggs imported from Norway in 1985 were hatched in Le Conquet hatchery (Brittany) under natural photoperiod and water temperature. The fish were fed with manufactured dry pellets by automatic feeders (ration: $2 \%$ body weight/day). For these experiments only the upper modal group of the population was selected (see Boeuf et al., 1985) and kept from September 1985 until July 1986 in Ewos tanks $(2 \times 2 \mathrm{~m})$ at a density of about $100 \mathrm{salmon} / \mathrm{m}^{2}$. A week before the experiment, fish were transported to the Centre Oceanologique de Bretagne and allotted to seven tanks $(0.6 \times 0.6 \mathrm{~m})$ with 5-10 fish/tank. Fish were kept in freshwater and fed with the same pellets until the day before the experiment. During the experiment, fish were sampled every $4 \mathrm{~h}$ over a period of $24 \mathrm{~h}$. For each sampling time, all salmon were removed from one tank and bled. The different tanks being independent, it was possible to take these fish without disturbing the rest of the population. This experiment was repeated at three dates during the smolting period (11 March, 5 May and 15 July, 1986).

\section{Studies on parr and smolt (1987)}

Atlantic salmon eggs imported from Norway were introduced in Le Conquet hatchery in 1986 and the fish reared in similar conditions as previously described. In September preceding the smolting period, fish from the upper and lower modal groups of the population (see Boeuf et al., 1985) were placed in 
different Ewos tanks $(2 \times 2 \mathrm{~m})$. Fish were kept in freshwater until the end of the sampling program (July 1987).

\section{Sampling and biochemical analysis}

Animals were netted and stunned by cranial concussion without anesthesia. Blood samples were obtained from the posterior aorta with a heparinized syringe. For the developmental study of Atlantic salmon parr and smolts, blood collection was always performed at the same time of the day (9-11 a.m.). Plasma was collected after centrifugation of blood and kept frozen at $-20^{\circ} \mathrm{C}$ until analysis. Gill filaments were taken from some fish, rinsed in $0.25 \mathrm{M}$ sucrose buffered at $\mathrm{pH} 7.4$ and immediately frozen in liquid nitrogen. Gill $\left(\mathrm{Na}^{+}-\mathrm{K}^{+}\right)$ATPase was measured according to the method described by Lasserre et al. (1978). Plasma PRL levels were measured using the method of Prunet et al. (1985). Data were subjected to a one-way analysis of variance and the Newman-Keuls multiple range test was used to assess the significance of seasonal changes in plasma PRL levels and $\left(\mathrm{Na}^{+}-\mathrm{K}^{+}\right)$-ATPase activity. Differences at each sampling date between parr and smolt were assessed using Student's $t$ test.

\section{RESULTS}

Diel variations in plasma PRL during smolting of Atlantic salmon

In 1986, salmon used for this study were taken from the upper modal group of the population which showed a normal pattern of smolting as assessed by increasing gill $\left(\mathrm{Na}^{+}-\mathrm{K}^{+}\right)$-ATPase activity from March to May (Table 1). This parameter reached a plateau in mid-May and later in July decreased progressively. Measurement of plasma PRL levels in this population indicated a sig-

\section{TABLE 1}

Gill $\left(\mathrm{Na}^{+}-\mathrm{K}^{+}\right)$-ATPase activity and plasma PRL levels in the Atlantic salmon population used for the diel rhythm experiment (mean \pm s.e.m.)

\begin{tabular}{|c|c|c|c|c|c|c|c|c|}
\hline $\begin{array}{l}\text { Dates } \\
\text { (1986): }\end{array}$ & 11 Feb. & 4 Mar. & 14 Mar. & 8 Apr. & 21 Apr. & 15 May & 10 June & 11 July \\
\hline $\begin{array}{l}\left(\mathrm{Na}^{+}-\mathrm{K}^{+}\right) \cdot \\
\text { ATPase } \\
(\mu \mathrm{m} \text { Pi mg } \\
\left.\text { Prot. }^{-1} \mathrm{~h}^{-1}\right) \\
n=10\end{array}$ & $3.8 \pm 0.2$ & $4.2 \pm 0.4$ & $9.0 \pm 0.7$ & $13.0 \pm 1.8^{b}$ & $17.0 \pm 1.5^{b}$ & $21.2 \pm 1.4^{\mathrm{cb}}$ & $17.4 \pm 1.1^{\mathrm{b}}$ & $11.7 \pm 0.7^{b}$ \\
\hline $\begin{array}{l}\text { sPRL }(\mathrm{ng} / \mathrm{ml}) \\
n=8-10\end{array}$ & $8.1 \pm 2.2$ & $11.9 \pm 1.7$ & $2.4 \pm 0.6^{\mathrm{a}}$ & $5.0 \pm 1.2^{\mathrm{a}}$ & $4.2 \pm 0.9^{n}$ & $2.3 \pm 0.3^{a}$ & $3.4 \pm 0.7^{\mathrm{a}}$ & $1.5 \pm 0.2^{\mathrm{a}}$ \\
\hline
\end{tabular}

"Significantly different $(P<0.01)$ from values measured on 11 February and 4 March.

bSignificantly different $(P<0.01)$ from values measured from 11 February to 14 March.

'Significantly different $(P<0.01)$ from values measured from 8 to 21 April and from 10 June to 11 July. 
TABLE 2

Gill $\left(\mathrm{Na}^{+}-\mathrm{K}^{+}\right)$-ATPase activity and length $(\mathrm{mm})$ of Atlantic salmon smolts used in the diel rhythm experiments (mean \pm s.e.m.)

\begin{tabular}{lrcc}
\hline Dates: & $11-12$ March & $5-6$ May & $15-16$ July \\
\hline $\left.\begin{array}{l}\left(\mathrm{Na}^{+}-\mathrm{K}^{+}\right) \text {-ATPase } \\
(\mu \mathrm{m} \text { Pi mg Prot. }\end{array}{ }^{-1} \mathrm{~h}^{-1}\right)$ & $6.06 \pm 0.52$ & $17.3 \pm 0.9^{\mathrm{a}}$ & $10.5 \pm 1$ \\
$n=20$ & & & \\
$\begin{array}{l}\text { Length }(\mathrm{mm}) \\
n=20\end{array}$ & $132.7 \pm 2.9$ & $153.2 \pm 1.5$ & $183.6 \pm 2$ \\
& & & \\
\end{tabular}

aSignificantly different $(P<0.01)$ from values measured on 11 March and 15 July.

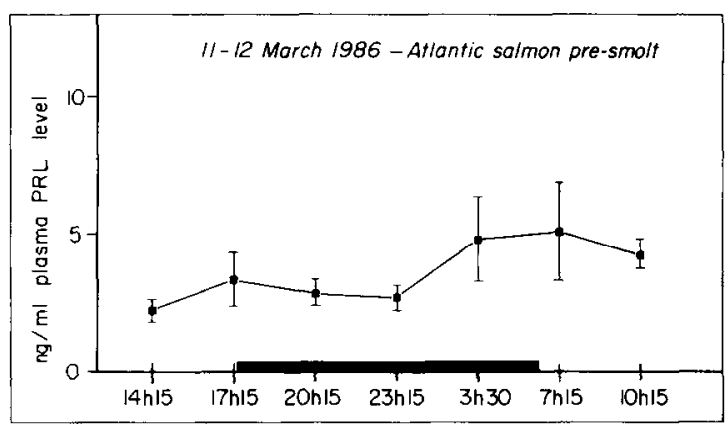

Fig. 1. Diel variations in plasma prolactin (PRL) levels (mean \pm s.e.m.) on 11-12 March over a 24-h period. Dark bar on the abscissa indicates the period of darkness. $n=5$.

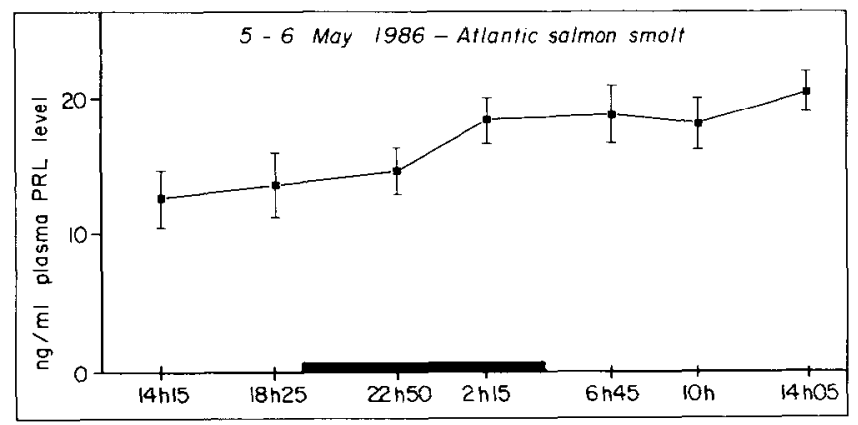

Fig. 2. Diel variations in plasma prolactin (PRL) levels (mean \pm s.e.m.) on 5-6 May. Dark bar on the abscissa indicates the period of darkness. $n=10$.

nificant decrease $(P<0.01)$ on March 14 followed by a long period of consistently low PRL levels (Table 1). Diel variations of plasma PRL were studied at three different dates: on 11 March during a period of increasing gill $\left(\mathrm{Na}^{+}-\right.$ 


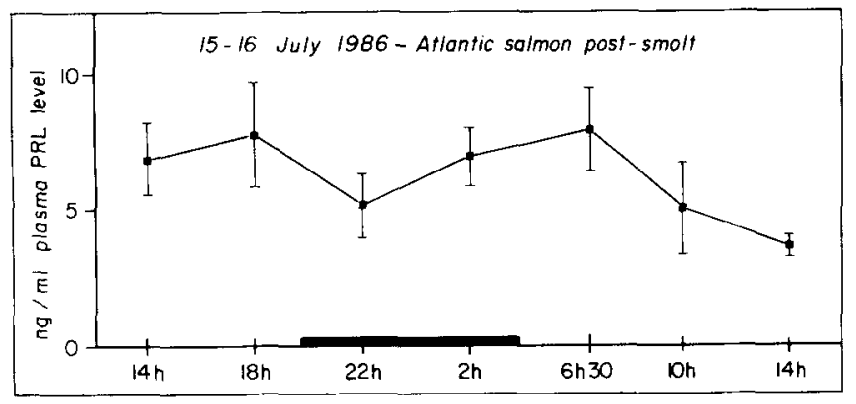

Fig. 3. Diel variations in plasma prolactin (PRL) levels (mean \pm s.e.m.) on 15-16 July. Dark bar on the abscissa indicates the period of darkness. $n=10$.

\section{TABLE 3}

Mean size $(\mathrm{mm})$ and gill $\left(\mathrm{Na}^{+}-\mathrm{K}^{+}\right)$-ATPase $\left(\mu \mathrm{m}\right.$ Pi mg Prot. $\left.{ }^{-1}, \mathrm{~h}^{-1}\right)$ activity of the two modal groups of Atlantic salmon populations in 1987

\begin{tabular}{lllllll}
\hline $\begin{array}{l}\text { Dates } \\
(1987):\end{array}$ & 5 Mar. & 17 Mar. & 7 Apr. & 21 Apr. & 12 May & 18 June \\
\hline
\end{tabular}

\section{Lower}

modal group

size $\left(\mathrm{Na}^{+}-\mathrm{K}^{+}\right)$-

$87 \pm 1.1 \quad 93 \pm 1.0 \quad 93 \pm 1.6 \quad 104 \pm 1.2 \quad 115.1 \pm 2.2 \quad 121.8 \pm 1.7$

ATPase

$\begin{array}{cccccc}3.9 \pm 0.7 & 5.4 \pm 0.8 & 6.4 \pm 0.7 & 7.3 \pm 1.2 & 10.4 \pm 1.8 & 4.6 \pm 0.5 \\ (n=30) & (n=26) & (n=22) & (n=13) & (n=12) & (n=16)\end{array}$

Upper

modal group

$\begin{array}{lccllll}\begin{array}{l}\text { size } \\ \left(\mathrm{Na}^{+}-\mathrm{K}^{+}\right)-\end{array} & 144 \pm 1.3 & 148.4 \pm 1.7 & 152.9 \pm 1.9 & 165.5 \pm 1.8 & 179.9 \pm 2.0 & 207.8 \pm 2.6 \\ \text { ATPase } & 8.8 \pm 0.9^{\mathrm{b}} & 10.4 \pm 1.2^{\mathrm{b}} & 18.2 \pm 1.4^{\mathrm{ab}} & 22.1 \pm 1.5^{\mathrm{ab}} & 17.6 \pm 1.2^{\mathrm{ab}} & 14.0 \pm 1.0^{\mathrm{b}} \\ & (n=10) & (n=10) & (n=10) & (n=10) & (n=10) & (n=10)\end{array}$

aSignificantly different $(P<0.01)$ from values measured on 5 March, 17 March and 18 June.

bSignificantly different $(P<0.01)$ from values measured at the same sampling date in the lower modal group.

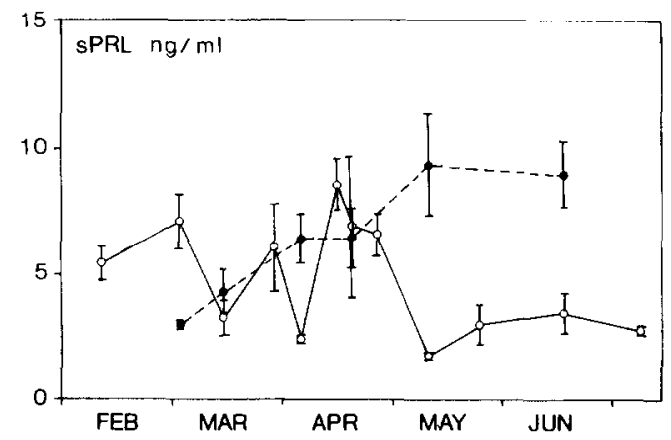

Fig. 4. Change in plasma prolactin (PRL) levels during spring 1987 in the two modal groups of an Atlantic salmon population reared in freshwater. o--o upper group $(n=10) ; \cdots$ lower group $(n=5)$. 
$\left.\mathrm{K}^{+}\right)$-ATPase; on 5 May when $\left(\mathrm{Na}^{+}-\mathrm{K}^{+}\right)$-ATPase was at its highest level; and on 15 July when the enzyme activity began to decline. Characteristics of the fish at these three dates are indicated in Table 2. No diel rhythm for plasma PRL was observed at any time according to a one-way analysis of variance $(P=0.05$, Figs. 1 to 3$)$.

Plasma PRL levels in parr and smolt from the same population

Both parr and smolts were followed in freshwater from February to July 1987. The two populations were clearly separated as indicated by their length and gill $\left(\mathrm{Na}^{+}-\mathrm{K}^{+}\right)$-ATPase activity (Table 3). In parr, plasma PRL levels increased steadily from February to the end of April and reached a plateau in May-June (Fig. 4). A significant $(P<0.05)$ increase was observed on 12 May when compared to values from 5 March. In smolts (Fig. 4), PRL levels showed a more variable pattern: until 7 April large fluctuations, although non-significant, were observed and were followed by a peak (PRL levels significantly higher $(P<0.05)$ on 17 April compared to 7 April). In May, PRL levels dropped and stayed low until early July $(P<0.05$ compared to values from 17 April $)$. When comparing PRL levels in parr and smolts at the same date, values were significantly $(P<0.01)$ different on 7 March and 7 April. However, the most obvious results were observed in May-June, with smolts showing consistently lower PRL levels compared to parr $(P<0.01)$.

\section{DISCUSSION}

It is now well established that PRL is a freshwater adapting hormone among different fish species. The ability of such fish to survive in freshwater after hypophysectomy is dependent on supplementation with exogenous PRL (see reviews by Loretz and Bern, 1982; Bern, 1983). In salmonids several studies indicated that PRL is not necessary for freshwater survival of hypophysectomized fish (Komourdjian and Idler, 1977; Björnsson and Hansson, 1983; Nishioka et al., 1987). However, measurements of plasma PRL levels in salmonids transferred to different salinities support a possible involvement of this hormone in freshwater adaptation (Hirano et al., 1985; Prunet et al., 1985). Few studies have focused on a possible role of this hormone during salmon smolting, and histological studies of pituitary PRL cells did not lead to a clarification of this problem (Nishioka et al., 1982). Recently, developmental studies of plasma PRL levels during coho and Atlantic salmon smolting were performed and showed a negative relationship between prolactin levels and hypoosmoregulatory ability (Prunet et al., 1989; Young et al., 1989). Particularly, a decrease in plasma PRL levels was observed during 3 months coinciding with the smolting time of Atlantic salmon. These experiments being performed under natural conditions, such plasma PRL changes could be explained in terms 
of seasonal hormone rhythms: thus, it was important to compare plasma PRL levels in both parr and smolts of the same age.

In our study, parr and smolt populations were separated according to their size (Boeuf et al., 1985) and the parr/smolt status of each population was confirmed by $\left(\mathrm{Na}^{+}-\mathrm{K}^{+}\right)$-ATPase measurement (Table 3$)$. A partially different pattern of PRL changes was observed in this study compared to the two previous years. Whereas PRL decreased in March in 1985 and 1986 (Table 1 and Prunet et al., 1989), in the present study (1987) such decreases occurred later and a PRL peak was observed in April (Fig. 4). Analyses of other biochemical parameters followed during these three years did not indicate any clear differences in thyroid hormone levels, $\left(\mathrm{Na}^{+}-\mathrm{K}^{+}\right)$-ATPase activity or hypoosmoregulatory ability (Boeuf et al., 1989; Prunet et al., 1989). So no clear hypothesis could be drawn from these data. However, high levels of plasma PRL have already been observed in smolts and a possible relationship with stress was suggested (Prunet et al., 1989; Avella et al., submitted).

In the parr population, we observed a steady increase of PRL levels which, interestingly, followed the increase in water temperature. By comparison with plasma levels measured in smolts, there was a clear indication that the PRL decrease observed in May-June was characteristic of a parr-smolt transformation. Although it would be tempting to find a causal relationship between such hormonal changes and development of hypoosmoregulatory ability in smolts, our results do not support such a hypothesis, as the PRL decrease was only observed late during the smolting period in 1987. However, data obtained in 1985 and 1986 suggest such a possibility (Prunet et al., 1989). It is clear that this problem deserves more investigation.

Daily rhythms of plasma concentrations of PRL were described in three fishes, the goldfish, Carassius auratus, kokanee salmon, $O$. nerka and mullet, Mugil cephalus (see review Meier, 1975; Sage, 1985). In the present study it was not possible to establish a diel rhythm of plasma PRL in Atlantic salmon during smolting. This is in agreement with studies performed on cannulated rainbow trout which did not show any diel variations over a 24 -h period (Prunet and Ollitrault, unpubl. data, 1987). The discrepancy with other data indicating a marked circadian rhythm in juvenile kokanee salmon may come from the use, in this previous study, of a heterologous radioimmunoassay for PRL measurement or possibly by a species difference (Leatherland et al., 1974). Interestingly, in our study this absence of PRL diel variation was observed during the smolting period at three different dates corresponding to pre-smolt, smolt and post-smolt. Before all three diel experiments, Atlantic salmon smolts were feeding normally, suggesting absence of any chronic stress which may have masked a possible diel rhythm (Bry and Zohar, 1980). Thus, the present plasma PRL decline observed during smolting (Fig. 4 and Prunet et al., 1989) cannot be explained by a change of a PRL diel rhythm. During the 5-6 May experiment, plasma PRL values were higher than values measured in the same pop- 
ulation kept in the hatchery (Table 1). A possible stress effect due to transport and/or new rearing conditions may explain such a discrepancy, although, as indicated above, fish were feeding normally. This problem was only observed in fully smolted fish which may indicate the higher sensitiveness to external stimuli at this stage (Simpson, 1985; Thorpe et al., 1987).

In summary, we have demonstrated in this study that the parr-smolt transformation is associated with a decrease of plasma PRL levels which cannot be explained by a PRL daily rhythm change. The importance and the exact role of PRL in the control of the different physiological processes involved during smolting need to be clarified.

\section{REFERENCES}

Avella, M., Schreck, C.B. and Prunet, P., Plasma prolactin and cortisol concentrations of stressed coho salmon, Oncorhynchus kisutch, in freshwater or saltwater. Gen. Comp. Endocrinol., submitted.

Barron, M.G., 1986. Endocrine control of smoltification in anadromous salmonids. J. Endocrinol., 108: 313-319.

Barton, B.A., Schreck, C.B., Ewing, R.D., Hemmingsen, A.R. and Patino, R., 1985. Changes in plasma cortisol during stress and smoltification in coho salmon, Oncorhynchus kisutch. Gen. Comp. Endocrinol., 59: 468-471.

Bern, H.A., 1983. Functional evolution of prolactin and growth hormone in lower vertebrates. Am. Zool., 23: 663-671.

Björnsson, B.Th. and Hansson, T., 1983. Effects of hypophysectomy on the plasma ionic and osmotic balance in rainbow trout, Salmo gairdneri. Gen. Comp. Endocrinol., 49: 240-247.

Boeuf, G., Le Roux, A., Gaignon, J.L. and Harache, Y., 1985. Gill $\mathrm{Na}^{+}-\mathrm{K}^{+}$-ATPase activity and smolting in Atlantic salmon (Salmo salar L.) in France. Aquaculture, 45: 73-81.

Boeuf, G., Le Bail, P.Y. and Prunet, P., 1989. Growth hormone and thyroid hormones during Atlantic salmon, Salmo salar L., smolting, and after transfer to seawater. Aquaculture, 82: 257268.

Bolton, J.P., Takahashi, A., Kawauchi, H., Kubota, J. and Hirano, T., 1986. Development and validation of a salmon growth hormone radioimmunoassay. Gen. Comp. Endocrinol., 62: 230238.

Bolton, J.P., Collie, N.L., Kawauchi, H. and Hirano, T., 1987. Osmoregulatory actions of growth hormone in rainbow trout Salmo gairdneri. J. Endocrinol., 112: 63-68.

Bry, C. and Zohar, Y., 1980. Dorsal aorta catheterization in rainbow trout (Salmo gairdneri). II. Glucocorticoid levels, hematological data and resumption of feeding for five days after surgery. Reprod. Nutr. Develop., 20: 1825-1834.

Folmar, L.C. and Dickhoff, W.W., 1981. Evaluation of some physiological parameters as predictive indices of smoltification. Aquaculture, 23: 309-324.

Grau, E.G., Nishioka, R.S., Specker, J.L. and Bern, H.A., 1985. Endocrine involvement in the smoltification of salmon with special reference to the role of thyroid gland. In: B. Lofts and W.N. Holmes (Editors), Current Trends in Comparative Endocrinology. Hong Kong University Press, Hong Kong, pp. 491-493.

Hirano, T., Prunet, P., Kawauchi, H., Tokahashi, A., Kubota, J., Nishioka, R.S., Bern, H.A., Takada, K. and Ishii, S., 1985. Development and validation of a salmon prolactin radioimmunoassay. Gen. Comp. Endocrinol., 59: 266-276.

Komourdjian, M.P. and Idler, D.R., 1977. Hypophysectomy of rainbow trout, Salmo gairdneri, and its effects on plasmatic sodium regulation. Gen Comp. Endocrinol., 32: 536-542. 
Langhorne, P. and Simpson, T.H., 1986. The interrelationship of cortisol, gill $\mathrm{Na}^{+}-\mathrm{K}^{+}-\mathrm{ATPase}$, and homeostasis during the parr-smolt transformation of Atlantic salmon (Salmo salar L.). Gen. Comp. Endocrinol., 61: 203-213.

Lasserre, P., Boeuf, G. and Harache, Y., 1978. Osmotic adaptation of Oncorhynchus kisutch Walbaum. I. Seasonal variations of gill $\mathrm{Na}^{+}-\mathrm{K}^{+}$-ATPase activity in coho salmon, $0^{+}$-age and yearling, reared in fresh water. Aquaculture, 14: 365-382.

Leatherland, J.F., McKeown, B.A. and John, T.M., 1974. Circadian rhythm of plasma prolactin, growth hormone, glucose and free fatty acid in juvenile kokanee salmon, Oncorhynchus kisutch. Comp. Biochem. Physiol., 47A: 821-828.

Loretz, C.A. and Bern, H.A., 1982. Progress in neuroendocrinology. Prolactin and osmoregulation in vertebrates. An update. Neuroendocrinology, 35: 292-304.

Meier, A.H., 1975. Chronophysiology of prolactin in the lower vertebrates. Am. Zool, 15: 905-916.

Nishioka, R.S., Bern, H.A., Lai, K.V., Nagahama, Y. and Grau, E.G., 1982. Change in the endocrine organs of coho salmon during normal and abnormal smoltification - an electron microscope study. Aquaculture, 28: 21-38.

Nishioka, R.S., Richman, N.H., Young, G., Prunet, P. and Bern, H.A., 1987. Hypophysectomy of coho salmon (Oncorhynchus kisutch) and survival in fresh water and seawater. Aquaculture, 65: 343-352.

Prunet, P., Boeuf, G. and Houdebine, L.M., 1985. Plasma prolactin levels in rainbow trout during the adaptation to different salinities. J. Exp. Zool., 235: 187-196.

Prunet, P., Boeuf, G., Bolton, J.P. and Young, G., 1989. Smoltification and seawater adaptation in Atlantic salmon (Salmo salar): plasma prolactin, growth hormone and thyroid hormones. Gen. Comp. Endocrinol., 74: 355-364.

Sage, M., 1985. The chronobiology of prolactin in bony fishes. In: B. Lofts and W.N. Holmes (Editors), Current Trends in Comparative Endocrinology. Hong Kong University Press, Hong Kong, pp. 563-566.

Simpson, T.H., 1985. Epilogue. Aquaculture, 45: 395-398.

Thorpe, J.E., McConway, M.G., Miles, M.S. and Muir, J.S., 1987. Diel and seasonal changes in resting plasma cortisol levels in juvenile Atlantic salmon, Salmo salar L. Gen. Comp. Endo crinol., 65: 19-22.

Young, G., Björnsson, B.T., Prunet, P., Lin, R.J. and Bern, H.A., 1989. Smoltification and seawater adaptation in coho salmon (Oncorhynchus kisutch): plasma prolactin, growth hormone, thyroid hormones and cortisol. Gen. Comp. Endocrinol., 74: 346-354. 